\title{
A Study on the Fractal Dimensions and Geological Condition of Landslides
}

\author{
Tetsuya KUBOTA*
}

\begin{abstract}
要 約
地すべりの危険箇所や危険度調查においては極力少数の要因を用いて定量的な判定ができることが望ましい。そ の観点から, 地すべり面積率や箇所数では表現できず，これまで定性的にのみ表現されて来た発生形態の複雑さを 定量的に表現するフラクタル次元 D を用いた危険度判定が有意義なものと思われる（久保田 1994）。本研究では, 特に地質情報と D との関係に着目，その間に有意な関係があるかどうかを検討し，初生を含めた地すべりの危険箇 所・危険度判定要因としての有用性を考察した。その結果，Dは実際の地すべりにおいて地質ごとに判別可能な程 度に有意な差をもち, 地質から D すなわち発生形態を含めた地すべりの定量的な概略の危険度を判断することに利 用可能と思われるので報告する。
\end{abstract}

キーワード: 地すべり地形, 地形要素, フラクタル*, 危険度*

\section{Introduction}

It is desirable to know the location of landslide susceptible areas in order to avoid landslide disasters. However, it is very difficult to find such places especially if they are concerning to primarily landslides. For this reason, topographical and geological features over the areas to investigate have been using to find out that kind of areas. In this paper, topographical "Fractal" characteristics of landslides are discussed on the view of the tool for investigation of landslide susceptible areas and their risk level. The "Fractal" is a mathematical theory that has developed by B. Mandelbrot in order to describe the quality of complex shapes or images in the nature. And, it is suitable for measuring landslides complex topography. Here in this paper, Fractal Dimension of landslides " $D$ " are discussed as a index factor for landslide risk level especially for primarily landslides. And the relation between $\mathrm{D}$ of actual landslides and geology are investigated here with multi-discriminant analysis. Finally, it has come to be clear that " $D$ " can be an index for landslides susceptibility or risk level.

\section{Study Method}

The self-affinity of landslides landform and meaning of the landslides fractal dimension $\mathrm{D}$ were discussed in former study (Kubota 1994), concluded that the self-affinity can be guaranteed as long as it is applied for adjacent landslide group within distance of $1 \mathrm{~km}$, and D means complexity of group landslide occurrence i. e. risk level of landslides. On this point of view, the relation between one of the important susceptibility factor "geology" and " $D$ " is considered here to obtain a standard index for landslide risk analysis.

To acquire the Fractal Dimension "D", so called Box Counting Method is adopted in this study like as former study (Kubota 1994), that is suitable for the 2 -dimensional images like landslides group landform, using actual landslides in Hyogo, Tottori, Okayama, as well as one from Niigata prefecture (Fig. 1).

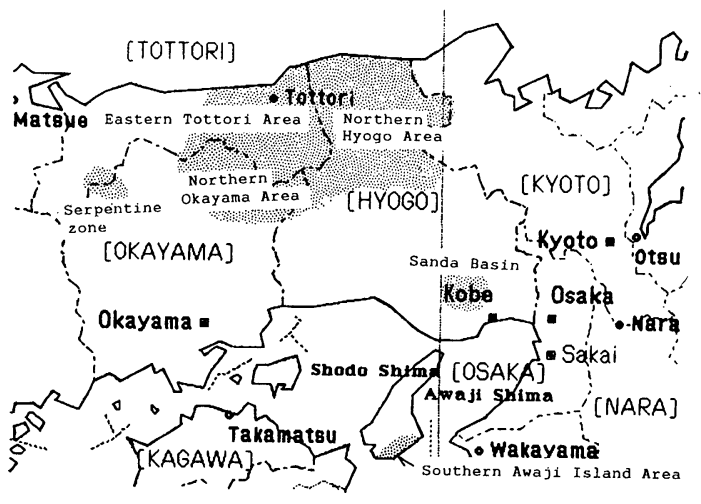

Fig. 1 Location of the Target Landslides Areas.

* Dept. of Environmental Science, Faculty of Agriculture, 
Each $\mathrm{D}$ is gained by the line slope derived from regression analysis, and classified with the geology. Then, all $\mathrm{D}$ are provided for the multi-discriminant analysis among different geologies, checked by Wilks' $\Lambda$-Test which can be reduced F-test.

\section{The Object Field of this Study}

The field in which the target landslides are situated consists of areas in Northern Hyogo, Sanda Basin (Hyogo pref.), Southern Awaji Island (Hyogo pref.), Eastern Tottori, Northern Okayama, Serpentin zone (Western Tottori pref., Northern Okayama pref.) and Jōetsu (Niigata pref.; for comparison). These areas have mainly geology of Tertiary madstone or tuff, on the other hand Serpentin zone has geology of crushed serpentin, and Southern Awaji Island area has tectonically crushed mesozoic sandstone madstone alternated beds (Shattered zone). In Northern Hyogo, it is divided into two formations called Hokutan Formations (mainly madstone), Teragi Formations (mainly tuff). The geology in Sanda Basin is represented by Kobe Formations (mainly madstone) that shows slight Cuesta structure, and Southern Awaji Island area has Izumi Formations (mainly madstone). Eastern Tottori area consists of Tottori Formations (madstone, tuff), while Northern Okayama area is formed by Katsuta Formations (madstone, shale, tuff). Adding to that, Serpentin zone consists of Paleozoic metamorphic rock like, of course, mainly serpentin and schist, whereas Jöetsu area consists of Tertiary Teradomari-Shiiya Formations (madstone) with andesite intrusive rock structure (Editorial committee of KINKI 1987, Editorial committee of CHUGOKU 1987, Editorial committee of CHUBU I 1988, Nakamura et. al. 1987)

\section{Results}

\subsection{Fractal Dimension "D"}

Box Counting diagram is shown in Fig. 2. In this figure, " $D$ " has a relation to the number of meshes $\mathrm{N}$ $(\eta)$ that includes landslide and the width of the rectangular meshes $\eta$ as form of below.

$$
D=-d(\ln N(\eta)) / d(\ln \eta)
$$

, here $d$ means differential.

Fractal dimensions gained from this relation are in Tab. 1 with correlation coefficient by regression analysis. And actual landforms are given in Fig. 3.

With Tab. 1 "D" can be found to take the value of 1. $0 \sim 1.46$ whereas it should be $1.0 \sim 2.0$ for plane, and it can take 1. 1 1. 3 for river system (Kubota 1994, Feder 1988). D of landslides seems bit bigger than the one of rivers. It can be shown the fact that this $\mathrm{D}$ values are different from geology to geology if the number of landslides is exactly or approximately same as described in former study (Kubota 1994). The average $D$ is 1.26 for Northern Hyogo area that has Hokutan-Teragi Formations. And the ones for Sanda Basin, Eastern Tottori area, Northern Okayama area, Serpentin zone are 1. 29, 1. 34, 1. 14 and 1.20 respectively, while the each D for Southern Awaji area, Jōetsu area are 1. 18 and 1.39. According to these values, Fractal Dimension has sufficient discrepancy to express the risk level among areas that belong to each other geology. Since Fractal Dimension D is a landslide risk index because of its feature that describes landslide complexity and packing rate as it is mentioned in former study (Kubota 1994), the geology that has high $\mathrm{D}$ value is judged that it has high landslide risk. And it is obvious that D in the typical landslide zone like Jōetsu area seems to be bigger than others, but it doesn't make very bigger value.

\subsection{Multi-Discriminant Analysis}

This analysis is carried out, after the landslides are classified to 5 groups "Hokutan-Teragi, Kobe, Tottori, Katsuta Formation area, and Serpentine -Shattered zone" with geology. Since serpentine zone is understood to be formed in a shattered zone, this two group are combined together. Jōetsu area is not involved in the analysis, because it is only for $\mathrm{D}$ value comparison.

The result of multi-discriminant analysis is described in form of Wilks' $\Lambda$, and also the scatter diagram is given. Wilks' $\Lambda$ is defined by

$$
\Lambda=\mathrm{Sw} / \mathrm{St}
$$

here, Sw: within-class sum of squares, St: total sum of squares. The smaller $(\Lambda<1.0)$ it is, the more effective the discrimination is. With landslides classified above in this study, $\Lambda=0.577$ is gained. And it is reduced to F-distribution's "F" (Okuno et. al. 1971), and it is given as $F=4.04$ in this case. This value is lager than $F(0.025)=3.44$ for $2.5 \%$ significance level, i. e. these geological groups mentioned above are discriminated efficiently on the significance level of $2.5 \%$. The scattered diagram is given in Fig. 4 , as well. From this diagram, the "D" difference by geology i. e. landslide risk level difference is distinct, although Hokutan-Teragi Formation has certain variance in $\mathrm{D}$. 


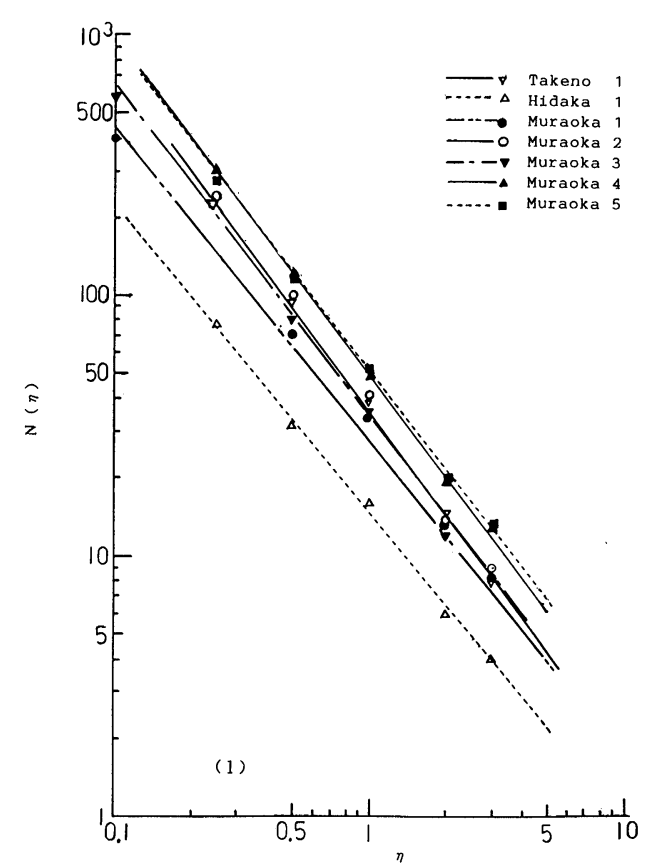

(1) Northern Hyogo

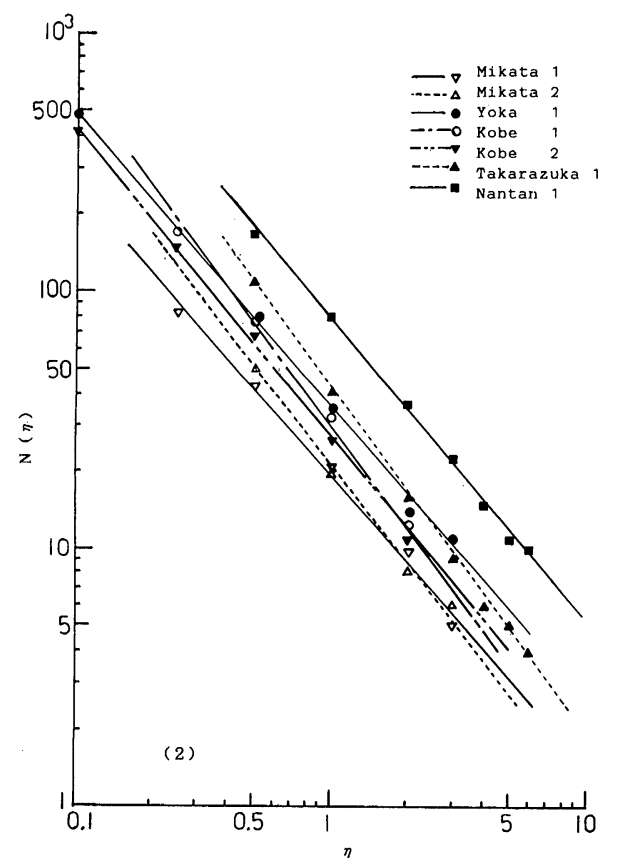

(2) Northern Hyogo, Sanda, Sourthern Awaji Island

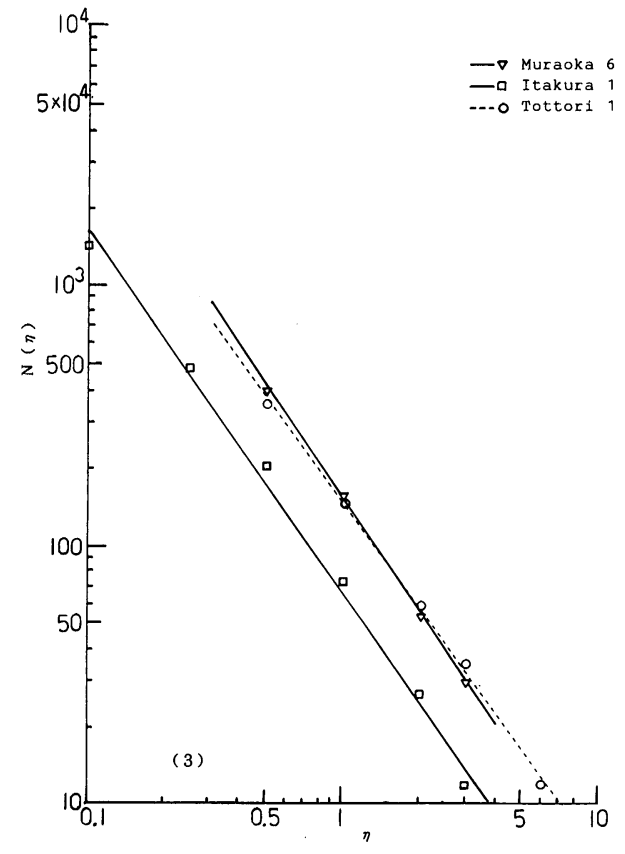

(3) Northern Hyogo, Eastern Tottori etc.

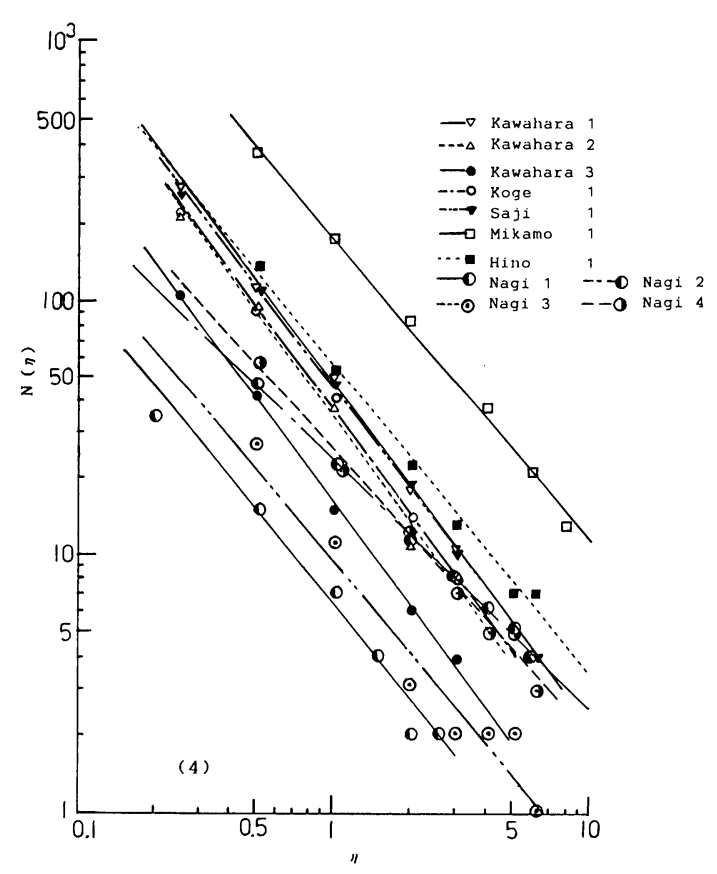

(4) Eastern Tottori, Northern Okayama etc.

Fig. 2 Box Counting Diagram (Relation between $\mathrm{N}(\eta)$ and $\eta$ ). 


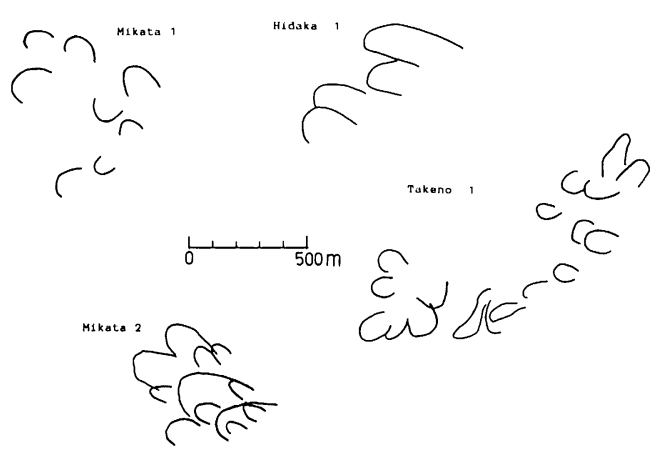

(1) Northern Hyogo

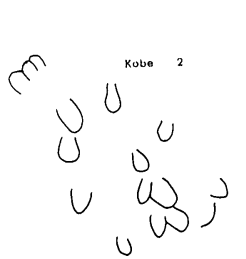

ก ?ח?

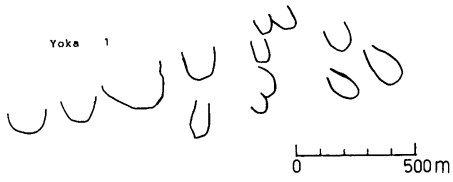

(2) Northern Hyogo, Sanda Basin

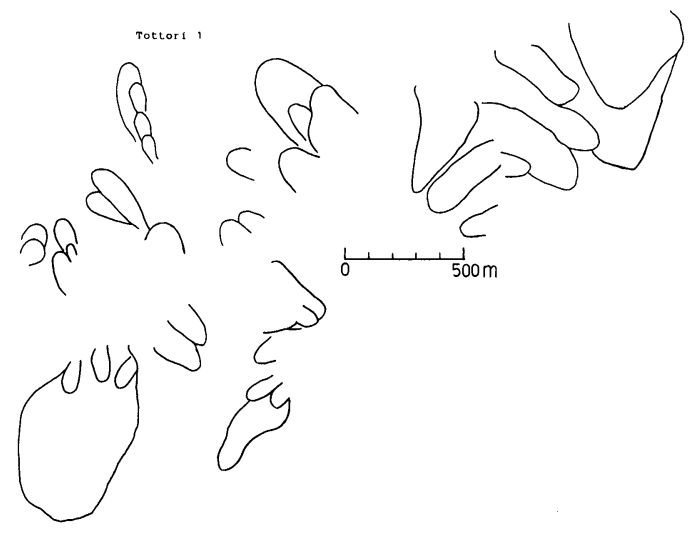

(3) Eastern Tottori

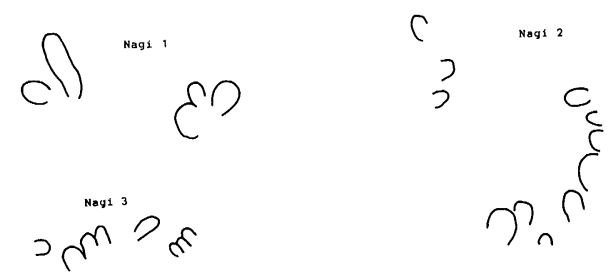

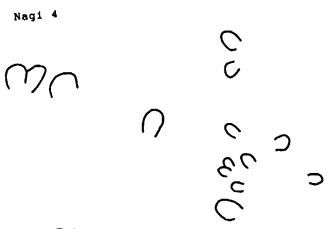

(4) Nothern Okayama

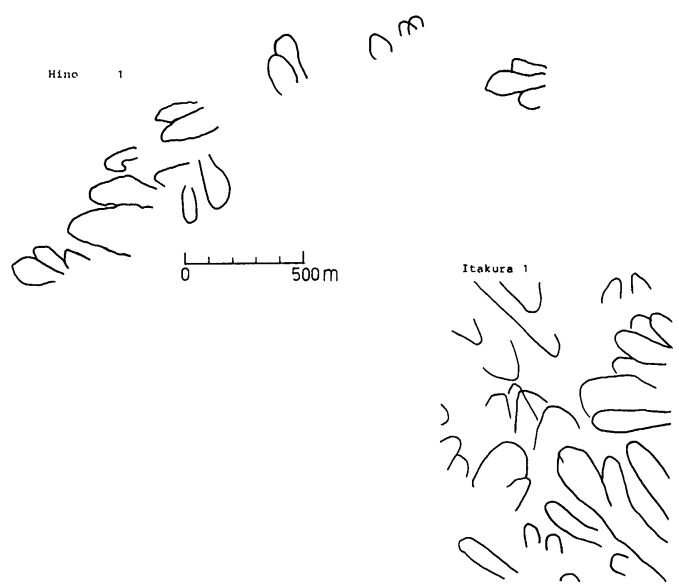

(5) Serpentine Zone, Jōetsu

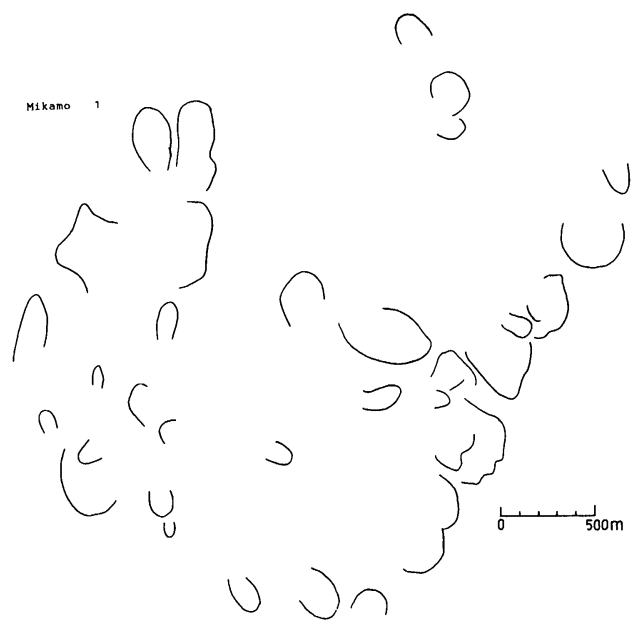

(6) Serpentine Zone

Fig. 3 Samples of the landslides landform (Typical examples). 


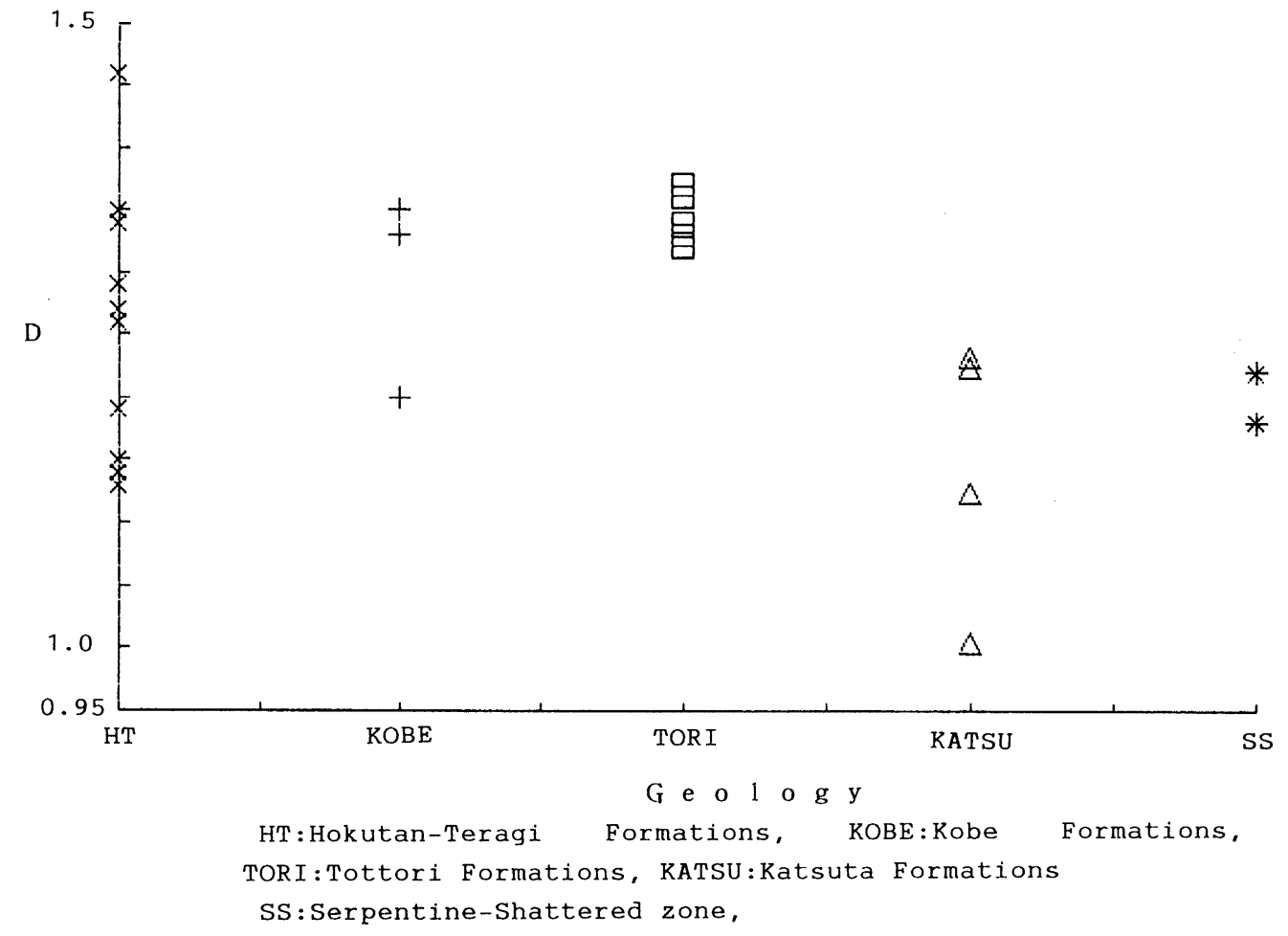

Fig. 4 Scattered Diagram of "D" for the Each Geology.

Tab. 1 Landslide Fractal Dimension of Each Area.

\begin{tabular}{|c|c|c|c|c|c|}
\hline No. & Area Name & Geology & D & $\mathrm{r}$ & $\mathrm{NL}$ \\
\hline 1 & H,Takeno 1 & HT & 1.34 & $\because 0.999$ & 18 \\
\hline 2 & H, Hidaka 1 & $\mathrm{HT}$ & 1.19 & -0.999 & 4 \\
\hline 3 & H,Muraoka 1 & $\mathrm{HT}$ & 1.15 & -0.999 & 7 \\
\hline 4 & H,Muraoka 2 & $\mathrm{HT}$ & 1.35 & -0.999 & 13 \\
\hline 5 & H, Muraoka 3 & HT & 1.27 & $=0.999$ & 20 \\
\hline 6 & H, Muraoka 4 & $\mathrm{HT}$ & 1.29 & 0.999 & 18 \\
\hline 7 & H,Muraoka 5 & $\mathrm{HT}$ & 1.26 & . 0.999 & 19 \\
\hline 8 & H,Muraoka 6 & $\mathrm{HT}$ & 1.46 & -0.999 & 53 \\
\hline 9 & H,Mikata 1 & $\mathrm{HT}$ & 1.13 & .0 .997 & 8 \\
\hline 10 & H, Mikata 2 & $\mathrm{HT}$ & 1.27 & $\therefore 0.997$ & 12 \\
\hline 11 & H,Yoka 1 & $\mathrm{HT}$ & 1.14 & -0.999 & 13 \\
\hline 12 & S, Kobe 1 & KOBE & 1.33 & -0.997 & 11 \\
\hline 13 & S, Kobe 2 & KOBE & 1.20 & -0.999 & 16 \\
\hline 14 & S, Takarazuka & KOBE & 1.35 & م99. 0.99 & 17 \\
\hline 15 & T, Tottori 1 & TORI & 1.36 & .. 0.999 & 40 \\
\hline 16 & T, Kawahara 1 & TORI & 1.33 & .0 .999 & 18 \\
\hline 17 & T, Kawahara 2 & TORI & 1.37 & 0.996 & 7 \\
\hline 18 & T, Kawahara 3 & TORI & 1.34 & 0.999 & 7 \\
\hline 19 & $\mathrm{~T}$, Koge 1 & TORI & 1.34 & -0.999 & 10 \\
\hline 20 & T,Saji 1 & TORI & 1.32 & -0.9995 & 13 \\
\hline 21 & 0, Nagi 1 & KATSU & 1.22 & . 0.991 & 5 \\
\hline 22 & $0, \operatorname{Nagi} 2$ & KATSU & 1.00 & .0 .999 & 11 \\
\hline 23 & 0, Nagi 3 & KATSU & 1.23 & -0.976 & 8 \\
\hline 24 & 0, Nagi 4 & KATSU & 1.12 & -0.994 & 14 \\
\hline 25 & Sp,Hino 1 & SS & 1.22 & - 0.997 & 19 \\
\hline 26 & Sp,Mikamo 1 & ss & 1.18 & -0.998 & 37 \\
\hline 27 & A, Nantan 1 & SS & 1.18 & -0.999 & 26 \\
\hline 28 & J, Itakura 1 & TS & 1.39 & 0.997 & 32 \\
\hline
\end{tabular}

Area; H:Northern Hyogo, S: Sanda Basin, T:Eastern Tottori, O: Northern Okayama, Sp;Serpentine zone, A:Southern Awaji Island, J:Niigata Jo-etsu Area.

Geology; HT: Hokutan-Teragi Formations, KOBE:Kobe Formations, TORI : Tottori Formations, KATSU:Katsuta Formations SS:Serpentine-Shattered zone, TS:Teradomari-Shiiya Formations.

$r$ : correlation coefficient, NL: numbers of the landslides.

\section{Conclusion}

As it is discussed so far,

(1) Fractal Dimension "D" takes the value of approximately 1.0 to 1.5 in the area above,

(2) each geology groups are distinguished by "D" that means landslide risk level, and it is obvious with the significance level of $2.5 \%$ by multi-discriminant analysis,

(3) therefore it can be available to acquire the susceptibility, especially the risk level for landslides concerning with geology.

Thus, it should be the important index to landslide risk level investigation including primary landslides at least for the specific area mentioned above, and it is believed that this study offers the effective information for landslide risk analysis.

\section{Acknowledgments}

I particularly wish to thank the members in the Sabo division of Hyogo prefectural government, the Sabo-Risui division of the Tottori prefectural government, and the Sabo division of the Okayama prefectural government for providing the landslides information that is very precious to proceed this study. 


\section{References}

1) Editorial committee of CHUBU I : Regional Geology of Japan Part 4 CHUBU I, Kyoritsu Shuppan CO., LTD. Tokyo, 1988, pp. 68 69, 249 252.

2) Editorial committee of CHUGOKU: Regional Geology of Japan Part 7 CHUGOKU, Kyoritsu Shuppan CO., LTD. Tokyo, 1987, pp. 113 114, 124 125, 211 $\sim 212$.

3) Editorial committee of KINKI: Regional Geology of Japan Part 6 KINKI, Kyoritsu Shuppan CO., LTD. Tokyo, 1987, pp. 138, 203 205.

4) Feder, Jens: Fractals, Plenum Press CO., LTD.
New York, 1988, pp. 220 223.

5) Kubota, Tetsuya.: A Study of Fractal Dimension of Landslides - The Feasibility for Susceptibility Index -, Journal of Japan Landslide Society, vol. 31 no. 3, 1994, pp. 9 15.

6) Nakamura, Hiroyuki. Kubota, Tetsuya.: Landslide Susceptibility from the Viewpoint of its Slope Angle and Geology, Journal of Japan Landslide Society, vol. 23 no. 4 , 1987, pp. $6 \sim 12$.

7) Okuno, Tadaichi. Kume, Hitoshi. Haga, Toshiro. Yoshizawa, Masasi.: Multivariate Analysis, Nikkagiren Press CO., LTD. Tokyo, 1971, pp. 300 384. （原稿受理日 平成 7 年 6 月 19 日） 


\begin{tabular}{|c|}
\hline 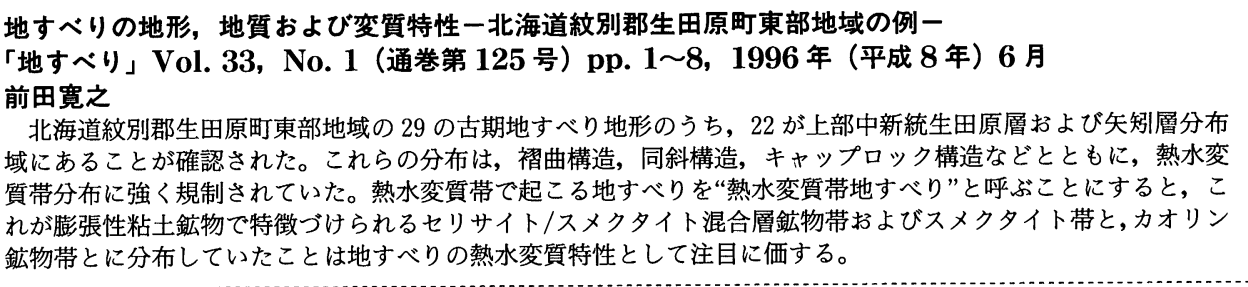 \\
\hline 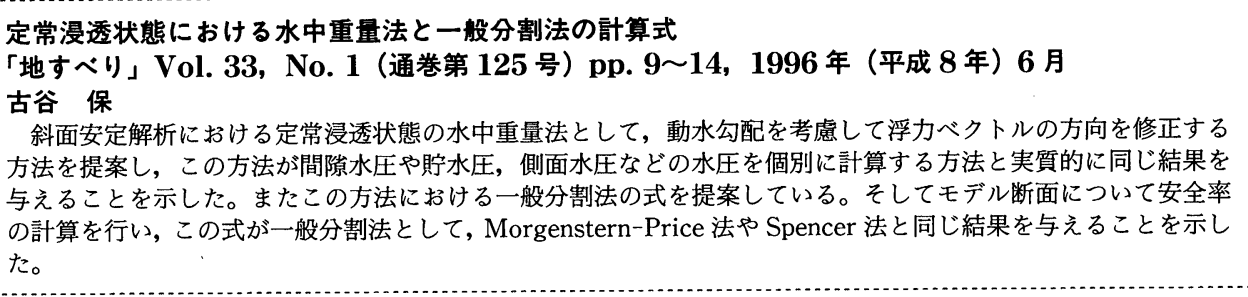 \\
\hline $\begin{array}{l}\text { ファジィネスを考虑した質点系モデルによる崩土の流下範囲の予測 } \\
\text { 「地すべり」Vol. 33, No. 1 (通巻第 } 125 \text { 号) pp. 15〜19,1996 年（平成 } 8 \text { 年）6 月 } \\
\text { 吉松弘行 } \\
\text { 崩土の流下範囲予測のため, 解析モデルの現実斜面の崩土挙動との不一致性及び斜面特性因子の計測誤差を } \\
\text { ファジィネスとして流下範囲の可能性について, 質点系モデルによる解析を実施し, 流下時の流動抵抗力が重要 } \\
\text { であることを示した。 }\end{array}$ \\
\hline $\begin{array}{l}\text { 東北地方の新第三紀・泥岩層における褟曲及び断層構造の成因と地すべりとの関連性 } \\
\text { 「地すへり」Vol. 33, No. 1（通巻第 } 125 \text { 号）pp. 20〜28, 1996 年（平成 } 8 \text { 年）6月 } \\
\text { 阿部真郎 } \\
\text { 我々は東北地方・グリーンタフ地域の地すべり多発地点において地すべりに関連して形成された褶曲, 断層構 } \\
\text { 造をいくつか確認した。これらは, 泥岩堆積当時の海底地すべり, 第四紀以降の初生的岩盤すべり及び現在に至 } \\
\text { る地盤隆起などによって形成されたものである。 }\end{array}$ \\
\hline 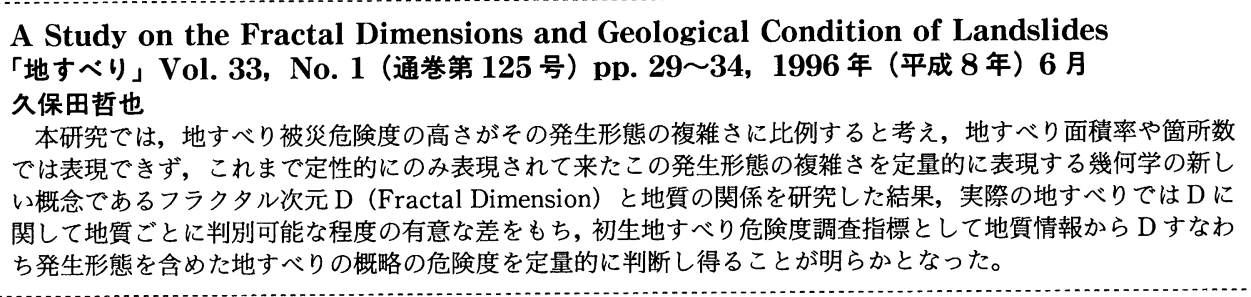 \\
\hline $\begin{array}{l}\text { 地すべり地におけるすべり面形状の推定に関する検討 } \\
\text { 「地すべり」Vol. } 33, \text { No. } 1 \text { (通巻第 } 125 \text { 号) pp. 35〜43, } 1996 \text { 年（平成 } 8 \text { 年）6 月 } \\
\text { 丸山清輝 } \\
\text { 本研究では, 現在移動を停止している地すべりのすべり面調査にも適用できるすべり面形状推定法を提案する } \\
\text { ことを目的として, 曖昧さが伴っているボーリングコア観察結果に, 地すべりブロックの形態とすべり面深度と } \\
\text { の統計的関係及び臨界すべり面解析結果を加え, 地質学的及び工学的に妥当なすべり面形状の推定法について検 } \\
\text { 討した。 }\end{array}$ \\
\hline 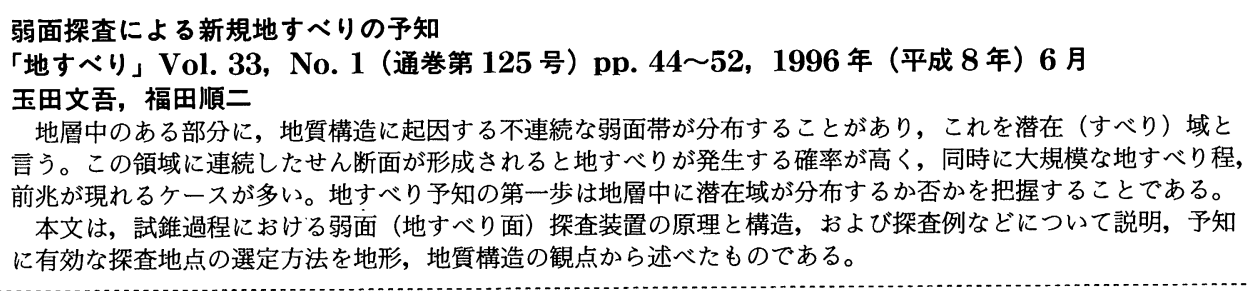 \\
\hline 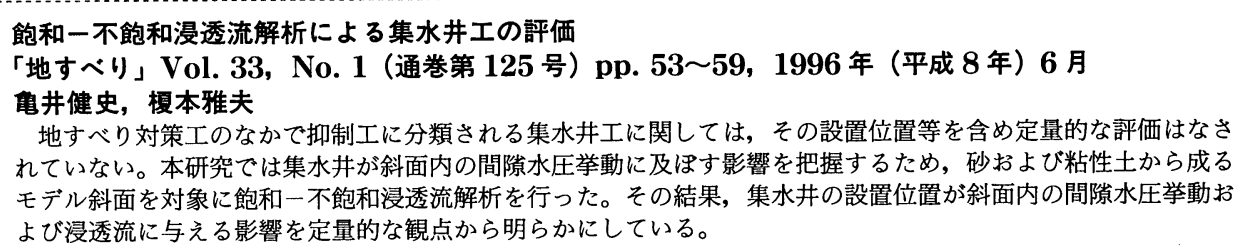 \\
\hline
\end{tabular}

